\title{
The Effect of Acupressure Therapy in Obstructive Sleep Apnea
}

\author{
Galih Jatnika, Susilawati Hartanto \\ STIKES Jenderal Achmad Yani Cimahi \\ Jalan Terusan Jenderal Sudirman - Cimahi 40533 \\ Email: galih_ikd@yahoo.com
}

\begin{abstract}
Obstructive Sleep Apnea (OSA) is a respiratory disorder during sleep with characteristics of temporary breathing cessation and upper airway obstruction that recurred partially or completely. Obesity has been recorded as one important risk factor in OSA. The purpose of this research was to assess the effect of acupressure therapy in OSA. This is a quasiexperimental study with pre-test and post-test one group design. Respondents were 18 high school students with BMI $>25 \mathrm{~kg} / \mathrm{m}^{2}$. OSA was assesed using Epworth Sleepiness Scale. Acupressure therapy was done at 10 acupoints for 10 consecutive days. Data was analyzed using dependent $t$ test. The results showed Epworth Sleepiness Scale score decreased significantly after acupressure therapy procedure (6.78 vs 5.28; p value 0.004). Conclusion, acupressure therapy can reduce the severity of OSA.
\end{abstract}

Keywords: acupressure, obesity, obstructive sleep apnea 


\title{
Pengaruh Terapi Akupresur terhadap Obstructive Sleep Apnea
}

\author{
Galih Jatnika, Susilawati Hartanto \\ STIKES Jenderal Achmad Yani Cimahi \\ Jalan Terusan Jenderal Sudirman - Cimahi 40533 \\ Email:galih_ikd@yahoo.com
}

\begin{abstract}
Abstrak
Obstructive Sleep Apnea (OSA) merupakan gangguan pernapasan ketika tidur dengan karakteristik penghentian napas sementara maupun obstruksi saluran pernapasan atas yang berulang secara parsial maupun total. Obesitas merupakah faktor risiko OSA yang penting. Tujuan penelitian ini untuk menilai efek terapi akupresur terhadap OSA. Metode penelitian yang digunakan adalah quasi experiment with pre-test and post-test one group design. Responden pada penelitian ini adalah 18 siswa SMA dengan IMT $>25 \mathrm{~kg} / \mathrm{m}^{2}$. OSA dinilai menggunakan Epworth Sleepiness Scale. Intervensi yang diberikan berupa terapi akupresur dengan pemijatan pada 10 acupoint selama 10 hari. Hasil dianalisa menggunakan uji $\mathrm{t}$ dependen. Hasil penelitian menujukkan rerata Epworth Sleepiness Scale mengalami penurunan bermakna setelah perlakukan $(6,78$ vs 5,28 , nilai $\mathrm{p} 0,004)$. Simpulan, terapi akupresur dapat memperbaiki OSA.
\end{abstract}

Kata Kunci: akupresur, OSA, obstructive sleep apnea 


\section{Pendahuluan}

Obstructive Sleep Apnea (OSA) adalah penghentian aliran udara selama beberapa detik yang terjadi saat tidur akibat penyempitan faring. Pada saat terjadi obstruksi ini, akan terjadi adanya penurunan aliran udara (hypopnea) sampai dengan berhenti secara total aliran udara (apnea). OSA merupakan gangguan pada saluran pernapasan saat tidur dimana terjadinya penutupan pharyng sebagian atau total, adanya periode hilangnya aliran udara, desaturasi oksigen dan sering menyebabkan penderitanya terjaga. ${ }^{1}$ Pada OSA sering didapatkan kebiasaan tidur mendengkur, sering terbangun malam hari, dan serangan berat rasa kantuk di siang hari. ${ }^{2}$

Etiologi OSA terdiri dari faktor kompleks yang saling memengaruhi berupa neural, hormonal, muskular dan struktur anatomi, misalnya akibat kegemukan terutama pada tubuh bagian atas, dipertimbangkan sebagai risiko utama untuk terjadinya OSA. Angka prevalensi OSA pada orang yang sangat gemuk adalah $42-48 \%$ pada laki-laki dan $8-38 \%$ pada perempuan. Penambahan berat badan akan meningkatkan gejala-gejala OSA. Obesitas merupakan sebuah kondisi kronis dimana terjadinya penumpukan lemak dalam tubuh sehingga melebihi batas yang baik untuk kesehatan. Seseorang dianggap menderita kegemukan (obesitas) bila indeks massa tubuh (IMT), yaitu ukuran yang diperoleh melalui hasil pembagian berat badan dalam kilogram dengan kuadrat tinggi badan dalam meter, lebih dari $25 \mathrm{~kg} / \mathrm{m}^{2} .{ }^{1}$

Mengutip data Riset Kesehatan Dasar Kemenetrian Kesehatan Republik Indonesia pada tahun 2013, secara nasional masalah gemuk pada anak usia 5-12 tahun masih tinggi, yakni, $18,8 \%$. Sedangkan prevalensi gemuk pada remaja usia 13-15 tahun sebesar 10,8\%. Data terbaru menunjukkan bahwa terdapat peningkatan angka kejadian obesitas. Berdasarkan data dari Riskesdas 2018 menunjukkan bahwa obesitas pada usia anak dan remaja dengan insidensi $10.8 \%$ - 18.8\%. ${ }^{3}$ Obesitas dapat meningkatkan risiko timbulnya berbagai macam penyakit seperti aterosklerosis, gangguan kardiovaskuler, hipertensi dan obstructive sleep apnea (OSA). ${ }^{4}$ Prevalensi OSA pada orang obesitas hampir dua kali lipat daripada responden dengan berat badan normal atau tidak obese dan juga menyebutkan kemungkinan bahwa obesitas dapat memperburuk OSA karena timbunan lemak pada lokasi spesifik. ${ }^{5}$ Hal ini diperkuat oleh pernyataan ahli yang menyatakan bahwa mendengkur keras, obesitas dan deposit lemak di leher bisa menjadi prediktor atau tanda klinik dari OSA. ${ }^{6}$ Seseorang dengan OSA akan sering terbangun di malam hari, sehingga tidur yang berkualitas tidak tercapai, padahal seseorang membutuhkan tidur berkualitas untuk mengembalikan keseimbangan tubuh baik secara fisik maupun secara psikologis. Kualitas tidur yang baik memberi berbagai manfaat positif seperti kondisi kesehatan yang lebih baik, tidak terserang mengantuk di siang hari, rasa nyaman, dan kondisi psikologis yang lebih baik. ${ }^{7}$ 


\section{Research Article}

Beberapa penanganan OSA yang dapat dilakukan meliputi penanganan bedah dan non bedah. Penanganan bedah dilakukan dengan pembedahan hidung; bedah plastik untuk palatum, uvula dan pharyng, somnoplasty atau trakeostomi. Penanganan OSA non bedah meliputi perubahan gaya hidup yang mencakup menurunkan berat badan, penggunaan obat-obatan yang membantu tidur, penggunaan bantal dan Continous Positive Airway Pressure (CPAP), dan terapi lain seperti relaksasi otot progresif, murottal Al Qur'an, terapi musik, dan terapi komplementer lain seperti akupresur. ${ }^{8}$

Akupresur merupakan tindakan penekanan pada titik-titik tertentu pada tubuh dan merupakan salah satu intervensi nonfarmakologis yang sangat efisien dan relatif cukup aman karena tidak melakukan tindakan invasif atau melukai kulit tubuh. Penekanan pada titik akupresur seperti pada titik meridian jantung HT7 (shenmen) secara fisiologis akan menstimulus peningkatan pengeluaran serotonin. Serotonin akan berperan sebagai neurotransmiter yang membawa sinyal ke otak untuk mengaktifkan kelanjar pineal memproduksi hormon melatonin. Hormon melatonin akan memengaruhi suprachiasmatic nucleus ( $\mathrm{SCN}$ ) di hipotalamus anterior otak dalam pengaturan ritme sirkadian sehingga terjadi penurunan sleep latency, nocturnal awakening, dan peningkatan total sleep time dan kualitas tidur. ${ }^{8}$ Terapi akupresur merupakan terapi sederhana, relatif aman dan mudah diterapkan. Pada bidang keperawatan, terapi ini dapat dilakukan oleh perawat dalam memberikan asuhan keperawatan mandiri yang membantu klien terbebas dari OSA.

Obstruksi jalan napas dapat menyebabkan peningkatan tahanan saluran napas atas, hipoksia, dan hipercapnia sehingga memicu penderita terbangun dari tidur. Remaja akan mengalami rasa kantuk berlebihan di siang hari, kelelahan, sering menguap, kurang perhatian, sulit berkonsentrasi, dan kemampuan mengingat terganggu dan bahkan bisa sampai menurunnya prestasi siswa tersebut. Gangguan OSA ini di Indonesia seringkali masih tidak terdiagnosis dan mendengkur saat tidur seringkali dianggap hal yang wajar. Apabila dibiarkan gangguan OSA ini bisa berdampak ke gangguan kualitas tidur, sering mengantuk di siang hari, kelelahan dan gangguan konsentrasi sampai dengan dampak yang berat berupa hipoksia, gagal jantung kongestif, stroke dan bahkan bisa menyebabkan kematian yang mendadak (sudden death). ${ }^{9}$ Hal ini menyebabkan peneliti merasa diagnosis dini berupa skrining risiko OSA pada remaja khususnya remaja dengan obesitas sangat diperlukan, demikian pula penelitian yang lebih lanjut untuk melihat keefektifan upaya pencegahan dan penatalaksanaan OSA dengan pemberian terapi akupresur. 


\section{Metode}

Metode penelitian yang digunakan pre-experimental pre-test and post-test one group design. Pemilihan subjek penelitian dilakukan berdasarkan perhitungan jumlah sampel numerik berpasangan dan didapatkan sebanyak 18 responden siswa-siswi SMAN 1 Cimahi dengan jenis kelamin pria sebanyak 9 responden dan perempuan sebanyak 9 orang. Responden yang diambil termasuk kategori obesitas dengan memiliki indek masa tubuh (IMT) $>25 \mathrm{~kg} / \mathrm{m}^{2}$. Indeks masa tubuh dihitung dengan cara membagi berat badan dengan tinggi badan kuadrat dalam satuan meter.

Pengukuran berat badan responden dilakukan menggunakan GEA body fat scale, pengukuran tinggi badan dilakukan menggunakan microtoise. Penentuan adanya risiko OSA dilakukan menggunakan parameter Epworth Sleepiness Scale. Intervensi akupresur dilakukan dengan melakukan pemijatan pada 10 acupoint, yaitu titik BL38, PC6, HT7, BL10, GV16, GB20, GV24.5, CV17, KI6, BL62. Terapi akupresur dilakukan sendiri oleh responden dengan pemijatan pada 10 acupoint tersebut dengan lama setiap pemijatan 5 detik, dan dilakukan pengulangan sebanyak 30 kali di setiap acupoint. Kekuatan pemijatan ditentukan sebesar $3 \mathrm{~kg}$ untuk menghindari penekanan berlebih ke jaringan tubuh dan khusus pemijatan titik B38 dibantu menggunakan 2 buah bola tennis. Durasi pemijatan selama 30 menit setiap hari dan dilakukan selama 10 hari. Pada hari ke sepuluh kembali dilakukan pengukuran Epworth Sleepiness Scale. Kekuatan penekanan sebesar $3 \mathrm{~kg}$ dilakukan dengan cara responden berlatih menekan dengan jari di bagian tengah timbangan digital sebanyak 30 kali berturut-turut dengan kesalahan penekanan tidak lebih $0,5 \mathrm{~kg} .{ }^{10}$ Analisa data univariat dilakukan menggunakan nilai frekuensi dengan persentase. Uji pengaruh dilakukan menggunakan uji t-dependent. Pengolahan data dilakukan menggunakan program SPSS versi 13. Penelitian ini dilaksanakan pada bulan Agustus - September tahun 2018 di SMAN 1 Cimahi dan telah mendapatkan surat persetujuan etik dengan nomor: 01/KEPK/XII/2018 dari Komite Etik Penelitian Kesehatan STIKES Jenderal Achmad Yani Cimahi. 


\section{Hasil}

Hasil penelitian dibuat dalam bentuk tabel dengan diberi penjelasannya dan disajikan pada Tabel 1 sebagai berikut:

Tabel 1 Karakteristik Responden Berdasarkan Nilai IMT

\begin{tabular}{lll}
\hline IMT & Frekuensi & $\%$ \\
\hline Overweight/Pre-obesitas & 2 & 11,1 \\
Obesitas & 16 & 88,9 \\
\hline Total & 18 & 100 \\
\hline
\end{tabular}

Berdasarkan hasil penelitian pada tabel 1 didapatkan bahwa sebanyak 2 responden $(11,1 \%)$ termasuk kategori overweight dan sebanyak 16 responden $(89,8 \%)$ termasuk kategori obesitas.

Tabel 2 Karakteristik Responden Berdasarkan Jenis Kelamin

\begin{tabular}{lllc}
\hline Kategori & Laki-laki & Perempuan & Jumlah \\
\hline Overweight & 1 & 1 & 2 \\
Obesitas & 8 & 8 & 16 \\
\hline Total & 9 & 9 & 18 \\
\hline
\end{tabular}

Selanjutnya pada tabel 2 tentang karakteristik responden berdasarkan jenis kelamin didapatkan bahwa dari 2 responden kategori overweight terdiri 1 orang laki-laki dan 1 orang perempuan dan dari 16 responden kategori obesitas terdiri dari 8 orang laki-laki dan 8 orang perempuan. Penentuan kategori IMT berdasarkan standar dari WHO yang dipublikasikan tahun 1995 pada National Institutes of Health di Amerika Serikat yang mengkategorikan nilai IMT underweight, normal, overweight dan obesitas. ${ }^{11}$ Jadi, pada hasil penelitian ini menunjukkan bahwa hampir seluruh responden termasuk kategori obesitas dan hanya 2 responden yang termasuk overweight. Obesitas dianggap sebagai faktor risiko timbulnya berbagai gangguan dalam tubuh termasuk salah satunya menjadi faktor risiko utama dalam perkembangan penyakit OSA. Hal ini sesuai dengan pendapat ahli yang mengatakan bahwa umumnya faktor risiko timbulnya OSA lebih banyak oleh karena obesitas, pertambahan $10 \%$ dari total berat badan dapat meningkatkan enam kali untuk mengalami progresivitas OSA. ${ }^{2}$ Dari beberapa pendapat tersebut dapat dinyatakan bahwa obesitas merupakan faktor risiko timbulnya OSA. 
Tabel 3 Perbedaan Rerata Epworth Sleepiness Scale Antara Sebelum dan Sesudah Diberikan Terapi Akupresur pada Responden

\begin{tabular}{llllll}
\hline & Rerata & $\mathrm{n}$ & $\mathrm{SD}$ & $\begin{array}{l}\text { Minimum- } \\
\text { Maksimum }\end{array}$ & $\mathrm{p}$ value \\
\hline Sebelum & 6,78 & 18 & 2,901 & $2-12$ & $0,004^{*}$ \\
Sesudah & 5,28 & 18 & 2,191 & $2-10$ & \\
\hline
\end{tabular}

Berdasarkan tabel 3 didapatkan bahwa rerata Epworth sleepiness scale sebelum diberikan terapi akupresur sebesar 6,78, dan setelah diberikan terapi akupresur sebesar 5,28. Terdapat perbedaan yang signifikan Epworth Sleepiness Scale antara sebelum dengan sesudah diberikan terapi akupresur $p$ value $0,004(\alpha<0,05)$. Terapi akupresur secara bermakna menurunkan gangguan OSA.

\section{Diskusi}

OSA merupakan gangguan kesehatan yang sudah banyak diteliti di luar negeri akan tetapi pada masyarakat kita gangguan ini belum banyak yang mengetahui. OSA apabila tidak ditangani akan berdampak terhadap peningkatan gangguan kesehatan, peningkatan pembiayaan kesehatan. OSA juga bisa berdampak ke peningkatan risiko kecelakaan seperti tabrakan ataupun kecelakaan di tempat kerja. OSA ini juga bisa berdampak pada peningkatan angka morbiditas dan mortalitas. Pada anak usia remaja apabila OSA ini dibiarkan bisa berdampak terhadap kualitas istirahat yang tidak cukup, dan di siang hari timbul mengantuk di siang hari yang dapat menyebabkan anak tidak mampu berkonsentrasi dengan baik saat belajar di sekolah. Hal ini apabila dibiarkan akan juga berdampak terhadap penurunan prestasi si remaja tersebut. Anak usia remaja yang rata-rata masih sekolah di tingkat SMP dan SMA memerlukan kondisi fisik yang baik agar terhindar dari timbulnya gangguan OSA. Adanya gangguan OSA pada remaja ini dapat dikaji dengan menggunakan Epworth sleepiness scale.

Epworth Sleepiness Scale merupakan parameter yang sederhana, yang dapat digunakan untuk mengkaji pada subjek adanya serangan rasa mengantuk di siang hari. Seseorang dengan OSA yang mengalami beberapa saat mengalami periode henti napas saat tidur akan berdampak terjadinya periode bangun dan tidur di malam hari sehingga kualitas tidur terganggu dan tidur fase rapid eye movement (REM) tidak akan tercapai. Hal ini akan berdampak adanya serangan rasa kantuk di siang hari. ${ }^{1}$ 
Epworth Sleepiness Scale merupakan alat ukur yang pertama kali dipublikasikan oleh Murray W Johns pada tahun 1991; skala ini dibuat untuk dapat mengkaji dengan lebih baik adanya serangan kantuk di siang hari dibandingkan beberapa parameter sebelumnya yang dianggap tidak praktis ketika dipakai untuk mengkaji OSA, diantaranya yaitu multiple sleep latency test dan Stanford Sleepiness Scale. ${ }^{12}$ Pada Epworth Sleepiness Scale, skor 5 - 15 menunjukkan OSA kategori ringan, 15 - 30 OSA kategori sedang, dan > 30 OSA kategori berat. Pada penelitian ini didapatkan rerata Epworth Sleepiness Scale sebelum terapi sebesar 6,78. Dari skala ini didapatkan responden rata-rata termasuk dalam gangguan OSA ringan. Rerata Epworth Sleepiness Scale setelah diberikan terapi akupresur didapatkan sebesar 5,28 dengan nilai $\mathrm{p}=0,004$; menunjukkan adanya penurunan Epworth Sleepiness Scale secara bermakna walaupun masih termasuk kategori gangguan OSA ringan.

Terapi akupresur merupakan pemijatan pada titik-titik meridian tubuh untuk membantu mengembalikan fungsi tubuh kembali ke kondisi sehat. Pada penelitian ini pemijatan dilakukan pada 10 acupoint dan pemijatan dilakukan oleh responden sendiri (self-acupressure). Acupoint pertama yaitu titik BL38 yang berada di bagian sisi kiri dan sisi kanan punggung diantara tulang scapula dengan tulang vertebra. Pemijatan ini sulit dilakukan sendiri oleh responden oleh karena lokasi titik BL38 berada di bagian punggung sehingga pemijatan dibantu dengan menggunakan bola tenis yang dilakukan dengan cara responden tidur terlentang di atas 2 bola tennis yang diletakan di bawah punggung responden. Pemijatan acupoint lainnya menggunakan jari telunjuk, jari tengah dan ibu jari. Acupoint tersebut yaitu titik PC6 yang lokasinya dua setengah jari dari pergelangan tangan, titik HT7 yang lokasinya di sisi pergelangan tangan sejajar jari kelingking, titik BL10 yang lokasinya di belakang leher sekitar $4 \mathrm{~cm}$ di bawah dasar tengkorak, titik GV16 yang lokasinya tepat di dasar tengkorak kepala bagian belakang, titik GB20 yang lokasinya berada di 2 sisi leher berjarak sekitar 5-7 cm dari dasar tengkorak, titik GV24.5 yang lokasinya diantara dua alis mata, titik CV17 yang lokasinya di ujung tulang sternum di bagian xyphoid process, titik KI6 yang lokasinya tepat di tulang angkel dan titik BL62 yang lokasinya di lekukan pertama di bagian bawah dari angkel. Lama penekanan untuk masing-masing acupoint yaitu 1 menit dilakukan sendiri oleh responden setiap hari selama 10 hari dengan selalu didampingi oleh peneliti. 


\section{Research Article}

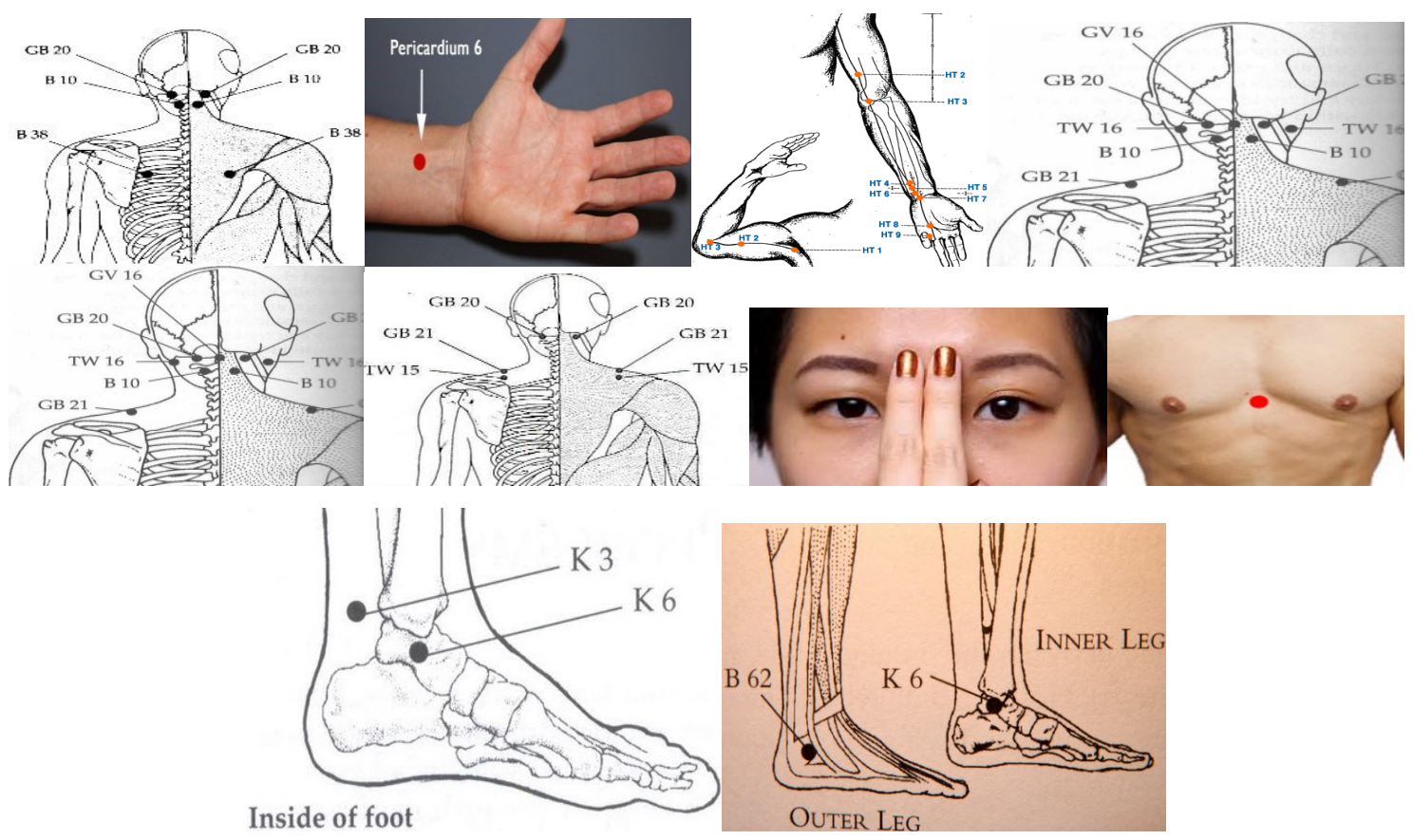

Gambar 1 Lokasi 10 Acupoint Terapi Akupresur

Hasil penelitian menunjukkan bahwa terapi akupresur berpengaruh secara signifikan untuk menurunkan gangguan OSA. Hal ini sejalan dengan hasil penelitian sebelumnya yang meneliti tentang pengaruh akupresur terhadap kualitas tidur wanita menopause, dinyatakan bahwa terapi akupresur pada empat titik yaitu titik shenmen (HT7) pada pergelangan tangan, titik sanyinjiao (SP6) pada kedua kaki, titik fengci (GB20) pada garis rambut di belakang leher (area oksipital) dan titik yintang di bagian atas hidung di antara kedua alis mata yang dilakukan setiap 2 jam sebelum tidur selama 4 minggu berturut-turut dapat memperbaiki kualitas tidur wanita menopause..$^{13}$

Hasil penelitian ini sejalan dengan penelitian Majid yang menyatakan bahwa terapi akupresur yang diberikan 6 kali selama 2 minggu pada 6 titik (titik zhao hai, sanyinjiao, shenmen, da ling, nei guan, yintang) dapat memperbaiki kualitas tidur lansia berdasarkan pengukuran kualitas tidur menggunakan Pitsburgh Sleep Quality Index. ${ }^{8}$ Penelitian yang dilakukan Xia-hong tentang pengaruh terapi akupresur aurikal (acupoint di bagian telinga) terhadap pola tidur pada pasien dengan OSA didapatkan hasil yang signifikan dalam meningkatkan indeks hipoventilasi, indeks gangguan respirasi dan lama tidur dan juga menurunkan waktu terbangun. ${ }^{14}$ Berbeda dengan penelitian sebelumnya bahwa pada penelitian ini lebih banyak banyak menggunakan acupoint yaitu 10 acupoint dan pada penelitian sebelumnya terapi diberikan hanya klien OSA dengan kategori gangguan sedang sampai dengan 


\section{Research Article}

berat sedangkan pada penelitian ini terapi akupresur diberikan pada klien OSA dengan gangguan kategori ringan. Penelitian terbaru yang dilakukan oleh Freire tentang pengaruh Manual Akupuntur (MA) dan Elektrikal Akupuntur (EA) terhadap pola tidur pasien dengan OSA didapatkan hasil satu sesi MA dan EA memberikan efek yang cepat (akut) dalam menurunkan angka AHI (Apnoea-Hypopnoea Index) pada pasien dengan OSA. ${ }^{15}$ Berdasarkan beberapa uraian tersebut dapat dinyatakan bahwa terapi akupresur terbukti dapat menurunkan keparahan dari gangguan OSA.

\section{Simpulan}

Berdasarkan penelitian ini disimpulkan bahwa terapi akupresur pada 10 acupoint setiap hari selama 10 hari dapat memperbaiki kondisi OSA, seperti terukur melalui Epworth Sleepiness Scale.

\section{Daftar Pustaka}

1. Jatnika G. Hubungan obesitas dengan risiko obstruktif sleep apnea pada mahasiswa di STIKES Jenderal Achmad Yani Cimahi. J K Kartika. 2018;12:29-36.

2. Mannarino MR, Fillipo FD, Pirro M. Obstructive sleep apnea syndrome. Eur J Int Med. 2012; 23:586-93.

3. Depkes. Riset Kesehatan Dasar. 2018.

4. Jatnika G, Hartanto S. Efforts in hypercholesterolemia treatment using turmeric (curcuminoid) extract phytotherapy on obese patients: preclinical study, J Kep Padjadjaran. 2018; 6 (3):227-34

5. Romero-Corral A, Caples SM, Lopez-Jimenez F, Somers VK. Interactions between obesity and obstructive sleep apnea: implications for treatment. Chest. 2010:711-9.

6. Semelka M, Wilson J, Floyd R. Diagnosis and treatment of obstructive sleep apnea in adult. Am Fam Physician. 2016;94(5):355-60.

7. Afianti N, Mardhiyah A. Pengaruh foot massage terhadap kualitas tidur pasien ICU. J Kep Padjadjaran. 2017; $5(1)$.

8. Majid YA. Pengaruh akupresur terhadap kualitas tidur lansia di Balai Perlindungan Sosial Tresna Werdha Ciparay. http://pustaka.unpad.ac.id/wp-content/uploads/2014/10/Pengaruh-Akupresur-Terhadap-Kualitas-TidurLansia.pdf

9. Lv ZT, Jiang WX, Huang JM., Zhang JM., Chen AM. The clinical effect of acupuncture in the treatment obstructive sleep apnea: A systemic review and meta analysis of randomized control trial. Ev based compl med.2016; 2016:879216.

10. Lin GH,Chang WC, Wei CC, Chen KJ, Tsai CC, Hu SY, Chen LL. Effectiveness of acupressur on the taichong acupoint in lowering blood pressure in patient with hypertension: a randomized clinical trial. Compl Alt Med Jour. 2016; 2016:1549658.

11. Nuttal FQ. Body Mass Index obesity, BMI and health: critical review. Wolters Kluwer Health Inc. Nutrition Today. 2015; 50:117-28.

12. Johns MW. A new method for measurement daytime sleepiness: Epworth Sleepiness Scale. Sleep. 1991 Dec;14(6):540-5.

13. Abedian Z, Eskandari L, Abdi H, Ebrahimzadeh S. The effect of acupressure on sleep quality in menopausal women: A randomized control trial. Iran J Med Sci.2015; 40(4):328-34.

14. Xia-hong W, Lan-yin X, Bao-fa W, Ya-dong Y, Wen-sen P, Yu-zhen S. Influence of auricular plaster therapy on sleeping structure in OSAS patient. J Tradit Chin Med. 2009; 29(1):3-5.

15. Freire AO, Sugai GC, Togeiro SM, Mello LE, Tufik S. Immediate effect of acupuncture on the sleep pattern of patients with obstructive sleep apnoea. Acupunct Med. 2010;28(3):115-9. 